\title{
姿勢の違いと人体の放射伝熱面積に関する研究 \\ RADIATIVE HEAT TRANSFER AREAS OF THE HUMAN BODY \\ IN RELATION TO THE POSTURE
}

\author{
藏 澄 美仁*1，土川忠浩*2，鳥居孝行*3，九手貴行*4 \\ 山下千華*5, 松原斎 樹*6, 堀 越哲 美*7 \\ Yoshihito KURAZUMI, Tadahiro TSUCHIKAWA, Takayuki TORII, Takayuki KUDE, \\ Chika YAMASHITA, Naoki MATSUBARA and Tetsumi HORIKOSHI
}

\begin{abstract}
The purpose of this paper is to offer the specific data for calculating the amount of heat exchange between the human body and environments by radiative heat transfer. The total body surface area was measured. Radiative heat transfer areas of the naked human body for the following nine body postures were measured: standing, chair sitting, seiza sitting, cross-legged sitting, sideway sitting, both-kneeserect sitting, leg-out sitting, lateral and supine postures. The results showed that the radiative heat transfer area of the naked human body in the standing posture was 0.773 , the chair sitting posture was 0.732 , the seiza sitting posture was 0.621 , the cross-legged sitting posture was 0.606 , the sideway sitting posture was 0.634 , the both-knees-erect sitting posture was 0.609 , the leg-out sitting posture was 0.686 , the lateral posture was 0.712 and the supine posture was 0.708 . The radiative heat transfer areas of the naked human body showed clearly that it is strongly influenced in the postures.
\end{abstract}

Keywords: heat transfer area of the human body, body surface area, heat exchange, radiation, posture 人体の伝熱面積，体表面積，熱交換，放射，姿勢

\section{1. はじめに}

温熱環境が人体へ与える影響を検討する従来の研究は、主にオフ ィス空間での軽作業を対象にしたものである。その研究の大部分は、 オフィス空調の設定目標値に関するものであり、必然的に姿勢なと の条件については非常に限定されたものとなる。これに対して、受 動的環境である実験室空間よりも能動的環境である生活空間では行 動の自由度が高いために、環境に働きかけをおこない温熱環境を調 節する行動性体温調節がおこなわれている。この一端には、姿勢を 変えることにより環境との間の熱交換量を調節することが挙げられ る。すなわち、通常の生活空間では姿勢条件にかなりの幅があり、 姿勢の条件を検討しなければ、実空間の設計には結び付き難い側面 がある。

演算装置の発達により、実験室空間から仮想空間での実験も多く おこなわれるようになってきている。しかし、仮想空間の実験にお いても姿勢などの多様性を設定条件に組込んだものは少ない。また、
シミュレーションによる仮想空間の設定温度を単に気温のみではな く、体感温度によって表現することは重要な研究の進展となる。し かし、姿勢に着目した体感温度を仮想空間でのシミュレーションに 反映させたものは極めて少ない。

体感温度は多くの温熱環境要素により構成されている。その構成 は、人体と周囲環境との間の熱収支を表現している熱平衡式に基づ いている。人体の熱平衡式は伝熱学的に記述されるが、熱量を算出 するには多くの人体に関わる数值を定めなければならない。その一 つに、人体に関わる伝熱面積がある。これには、人体の体表面積と 対流伝熱面積、放射伝熱面積、伝導伝熱面積が必要となる。通常、 人体の熱収支で取扱う熱量は人体の伝熱面積で基準化されている。

通常の室内環境での人体が強度な作業状態にあることや大きな風 速に曝されることは稀であることより、人体と周囲環境との間の熱 交換量の $50 \%$ 程度は放射による熱交換量となる。すなわち、人体 の熱平衡式を検討するには人体の放射伝熱面積を明らかにすること
*1 京都府立大学人間環境学部環境デザイン学科

助教授: 博士 (工学)

*2 兵庫県立大学環境人間学部環境人間学科

助教授 . 博士 (工学)

*3 高砂熱学工業(侏) 修士(学術)

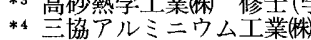

*5 株大京

*6 京都府立大学人間環境学部環境デザイン学科 教授・工博

*7 名古屋工業大学大学院ながれ領域 教授・工博
Assoc. Prof., Dept. of Environmental Design, Kyoto Prefectural University, Dr. Eng. Assoc. Prof., School of Human Science \& Environment, University of Hyogo, Dr. Eng.

Takasago Thermal Engineering Co., Ltd., M. Living Science

Sankyo Aluminium Industry Co., Ltd.

Daikyo Inc.

Prof., Dept. of Environmental Design, Kyoto Prefectural University, Dr. Eng.

Prof., Nagare College, Graduate School of Nagoya Institute of Technology, Dr. Eng. 
が重要な課題となる。

人体の放射伝熱面積に着目した研究は人体の有効放射面積を 求める研究としておこなわれてきた。

裸体立位姿勢の有効放射面積は多くの研究者 (Bohnenkamp and Pasquary, 1931'1); Bandow and Bohnenkamp, 19352); Bedford, 193533); Hardy and DuBois, 19384); Guibert and Taylor,

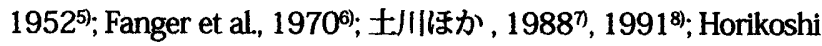

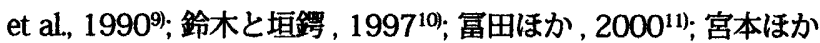
，2001 $\left.{ }^{12)}\right)$ により報告されている。しかし、いずれの研究とも、 人体と周团罟境との間の熱交換の経路では熱伝導に該当する床 面との接触面を有効放射面積に含んだ処理をしている。

裸体椅座位姿勢の有効放射面積は多くの研究者 (Guibert and Taylor, 19525); Fanger et al., 19706); 堀越と小林, 1982 ${ }^{13)}$; Kakitsuba et al., 198714); 土 川 $5,1988^{7}, 1991^{8)}$; Horikoshi et al., 19909); 鈴木と垣鋽， 199710); 富田ほか，2001 15); 宮本ほか， 200316)ににより報告されている。前述の立位の場合と同様に、 いずれの研究とも、床面・椅子面との接触面を有効放射面積に 含んだ処理をしている。

その他の姿勢についてはそれぞれ単独の研究成果のみの報 告に留まっている。裸体正座位姿勢の有効放射面積は藏澄ら $(1998 \mathrm{a})^{17}$ 、裸体胡座位姿勢の有効放射面積は宮本5 (1996) ${ }^{18}$ 、 裸体横座位姿勢の有効放射面積は藏澄ら (2005) $)^{19}$ 、裸体立て椯

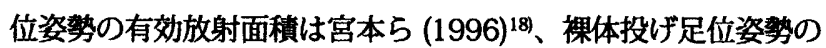
有効放射面積は藏澄5 (2005) $)^{19}$ 、裸体側臥位姿敏の有効放射面 積は水谷ら (1996) ${ }^{20)}$ や藏澄ら (2005) ${ }^{19}$ 、裸体仰臥位姿勢の有 効放射面積は藏澄ら (2005) ${ }^{19}$ が報告している。しかし、床面 との接触部分の熱交換を熱放射とするかまたは熱伝導とするか の取扱いに違いが認められる。

以上のように、人体の放射伝熱面積は、立位や椅座位の伝熱 面積を除き、他の姿勢での研究は極奴少ない。加えて、同一 人体での実測研究は皆無である。また、被験者比較や体型・体 組成比較をするには伝熱面積の基準値となる人体の体表面積が 重要となるが、この面積を実測して人体の伝熱面積を検討して いる研究は皆無である。

そこで、本研究では人体と周囲環境との間の熱交換量の基準 となる人体の伝熱面積に着目し、熱交換量の算定に必要である が末整備である熱平衡式で用いられる人体の放射伝熱面積を被 験者を用いた実測により明らかにし、基礎データとして供する こと、さらに、姿勢の違いによるその面積の造いを明らかにす ることで、その特性の一端を把握することを目的とした。

本研究は、人体の熱交換に関わる伝熱面積を姿勢の違いに着 目して実測した研究として位置づけられる。被験者は 1 名では あるが、新しいデータとして意義深いものと考える。

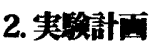

実験は、Fig. 1 k示す立位、椅座位、正座位、胡座位、横座 位、立て膝位、投げ足位、側卧位、仰臥位の姿勢別におこなった。 姿勢の定義は藏澄ら (2003b) $)^{21}$ に従った。

被䀦者は、ブリーフのみを着用したほぼ裸体状態にて実測に 参加した。頭部は頭髪の影響で体表面積が大きくなるが、実測
をおこなううえで、その影響を排除することが実測計画上困難 であったために、競泳用のシリコンキャップをかぶり実測をお こなった。

\section{1 休表面積の央讪方法}

体表面積の直接採取には、サージカルテープを直接体表面に 貼付し、その被覆に要したテープの面樌を測定する方法 (藏澄 ほか，1994)22)を用いた。

不織布サージカルテープ(ニチバン, ホワイトテープ 21N, 幅 $12,25,50,75 \mathrm{~mm}$ ) をテープが重なるように直接貼付した。テ 一プの重なる部分を油性ペンにてマーキングした後、テープ を1枚ずつ慎重に剥がし、ケント紙に貼り付けた。この重な ったテープ部分を除いたテープ表面をデジタイザ (Graphtec, KD4310，読み取り精度 $0.025 \mathrm{~mm}$ ) とコンピュータを用いて自作 のプログラムにより面積を求めた。

なお、外耳道は危険なために湘定対象とはしなかった。

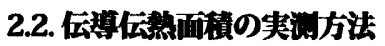

体表面と床面との間の伝導伝熱面積の抽出には透明フィルム 透写法 (藏澄ほか, 1997) 23) を用いた。透明アクリル版上で一 定の姿勢を維持した被験者とアクリル版との接触部分を透明フ イルムに透写した。なお接触部がより鮮明となるように、被匼 者の接触部近傍にはインクを塗布した。

抽出した体表部分の面積は体表面積の実測と同様の方法 (藏 澄ほか, 1994)222ににて実測した。

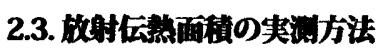

実測は立体角投射法則に基づく射影型式が正射影の魚眼レ ンズ (OP Fisheye Nikkor $10 \mathrm{~mm} \mathrm{f} / 5.6)$ と $35 \mathrm{~mm} 1$ 眼レフカメラ (Nikon F4) を用いた写真撮影法(堀越ほか， 1978)24)にておこな วた。

実測座標の原点は、人体の中心点である滕の奥 $0.1 \mathrm{~m}$ の位置 を通る鈶直線と床面との交点とした。床面を基準とした座標系 を設定し、原点か $50.5 \mathrm{~m} \times 0.5 \mathrm{~m}$ の格子点を実測位置とした。 人体を取り囲むために設定した人体下方床面 (座標原点から鉛 直方向に - $0.5 \mathrm{~m}$ の位置) の実測時には、透明なアクリル板で作 成した架台に人体を載せ空中に浮かせた状態を作り人体下方面 を設定した。

実測対象面は人体周囲を取囲む正面と背面、右側面、左側 面、床、天井に相当する矩形面とした。天井面は座標原点から 人体の水平面方向に $2.5 \mathrm{~m}$ の位置の面を実測対象とした。床面 は座標原点から人体の水平面方向に $-0.5 \mathrm{~m}$ の位置の面を実測対 象とした。左右の側壁面は座標原点から人体の前額面方向に左 右 $1.0 \mathrm{~m}$ の位膡の面を実測対象とした。正面壁と背面壁は、立 位と椅座位、正座位、胡座位、横座位、立て滕位、投け足位の 場合には座標原点から人体の矢状面方向に前後 $1.0 \mathrm{~m}$ 位置の面 を実測対象とした。側卧位と仰卧位の場合には座標原点から人 体の矢状面方向に前後 $1.5 \mathrm{~m}$ の位置の面を実測対象とした。

\section{4 被飨者}

被験者は実測時 30 藏の健康な成人男性 1 名とした。被験者 の身長は $174.80 \mathrm{~cm}$ 、体重は $62.978 \mathrm{~kg}$ であった。 Rohrel index は 117.91 であり、標準的な体型の被験者であった。2002年 の国民栄暜調查の 30 歳全国平均値 (厚生労働省保健医療局, 


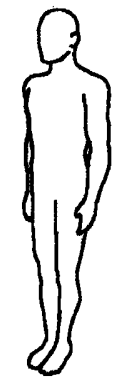

Standing

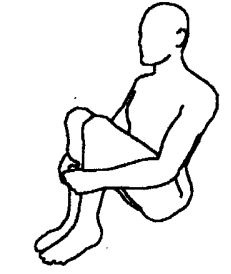

Both-knees-erect sitting

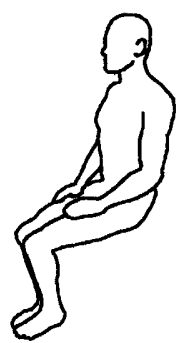

Chair sitting

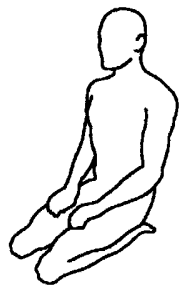

Seiza sitting

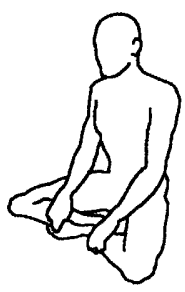

Cross-legged sitting

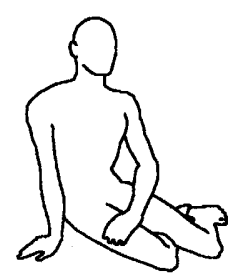

Sideway sitting

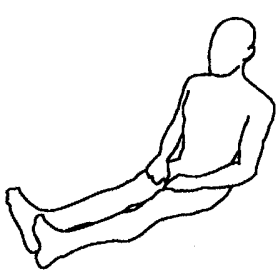

Leg-out sitting

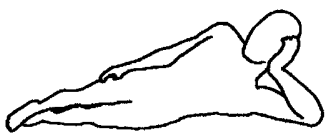

Lateral

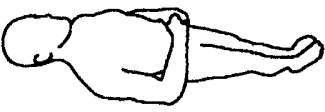

Supine

Fig. 1 Experimental postures.

2004) $)^{25)}$ との比較では、身長·体重とも標準偏差内の数値であり、 特異な体格の被験者ではないと考えられる。

なお、被験者には事前に実測内容を十分に説明し，実測に参 加する同意を得た。

\section{3. 実湔法果}

既存の研究の多くは、人体と床面との間の接触面積は小さく、 人体と床面との間の伝導による熱授受量は無視可能であると仮 定してきた。しかし、藏澄ら (1999) ${ }^{26)}$ の床暖房空間における 人体の熱収支に関する研究では、床座位 (胡座位、横座位、投 げ足位) や臥位姿勢は人体と床面との間の伝導による熱授受量 を含めて人体の熱収支を捉えることが必須であることを明らか にしている。そこで、本研究では人体の放射伝熱面積を人体と 空間構成面との熱放射授受に関わる人体の表面積とする。すな わち、椅子などが空間構成面と人体との間の熱放射を遮蔽する が、その遮蔽を無視するものとする。

\section{1 体表两皘の丰法果}

全体表面積の実測結果は $1811.6 \mathrm{~cm}^{2}$ となった。日本人の体 型や体組成が変化した後の日本人を対象に体表面積算出式の検

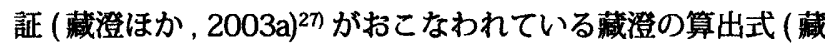
澄ほか，1994) 22) による算出值と実測結果とを比較すると、実 測結果は算出値よりも大きな值となり、その差は $2.1 \%$ となっ た。

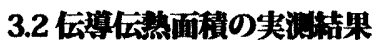

伝導伝熱面積の実測結果を Table 1 に示す。仰臥位の伝導伝 熱面積が最も大きく $1816.5 \mathrm{~cm}^{2}$ となった。一方、椅座位の伝 導伝熱面秸が最も小さく $152.3 \mathrm{~cm}^{2}$ となった。

正座位の伝導伝熱面積は $228.6 \mathrm{~cm}^{2}$ であり、立位の伝導伝熱 面積とほぼ同じである。床座位姿勢の中では顕著に小さい伝導 伝熱面積である。これは正座位が下腿部から足部の体表面で線 的に体を支えていることが影響している。他の床座位姿勢か下
肢部の体表面で面的に体を支えていることとは对照的な姿勢維 持状態である。

足部のみ床面と接触する立位の伝導伝熱面積は $230.8 \mathrm{~cm}^{2}$ で あった。床面との間の伝導伝熱面積がほぼ等しいと考えられて いた立位と椅座位の足部は、立位の場合がより大きな伝熱面積 となる結果となった。椅座位の姿勢維持の主要な部位は椅子の 座面と接触する蟹部・大腿部である。立位では全体重が足部で 支えられている。一方、椅座位では下肢部の重量のみが足部で 支えられている。これは藏澄ら (199723), 1998b ${ }^{28)}$ )、Kurazumi et al.(2004) ${ }^{29)}$ が指摘している様に、明らかに足部に加わる重量 の影響を示していると考えられる。

前述の様に、本研究では人体の放射伝熱面積を人体と空間構 成面との熱放射授受に関わる人体の表面積としている。したが って、人体と椅子との間の熱伝導による熱交換は検討しないが、 参考值として、事務用椅子との間の伝導伝熱面積を実測した。 体表面と椅子の座面・背もたれ面との間の伝導伝熱面積の抽出 には、対流伝熱面積の実測と同様の方法 (藏澄ほか, 2003b) ${ }^{21)}$ を用いた。事務用椅子に座った場合の座面と背隹れ面との間の 伝導伝熱面積は、それぞれ $625.8 \mathrm{~cm}^{2}, 300.6 \mathrm{~cm}^{2}$ となった。

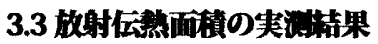

放射伝熱面積の実測結果を Table 1 に示す。立位の放射伝熱 面積が最も大きく $17062.2 \mathrm{~cm}^{2}$ となった。一方、胡座位の放射 伝熱面積が最も小さく $10973.8 \mathrm{~cm}^{2}$ となった。

体幹部と下肢部が相互に向い合い、下肢部を組合せる床座位 姿勢の正座位や胡座位、横座位、立て膝位の放射伝熱面積は他 の姿勢と比較して小さな値となった。これは、体表面どうしの 相互放射・接触の影響が大きいと考えられる。

いずれの姿勢とも、対流伝熱面積と比較して放射伝熱面積は 顕著に小さい。前述と同様に、体表面どうしの相互放射・接触 の影響が大きいためと考えられる。 
Table 1 Results of radiative heat transfer area of the human body.

\begin{tabular}{cccccccccc}
\hline Heat transfer area & Standing & Chair & Seiza & Cross & Sideway & Knee & Leg-out & Lateral & Supine \\
\hline $\mathrm{A}_{\mathrm{rad}}\left[\times 10^{-4} \mathrm{~m}^{2}\right]$ & 14009.1 & 13264.5 & 11244.1 & 10973.8 & 11490.0 & 11037.9 & 12427.7 & 12900.1 & 12828.1 \\
$\mathrm{~A}_{\mathrm{cod}}\left[\times 10^{-4} \mathrm{~m}^{2}\right]$ & 230.8 & 152.3 & 228.6 & 527.5 & 536.9 & 413.6 & 697.1 & 714.8 & 1816.5 \\
$\mathrm{f}_{\mathrm{rad}}[-]$ & 0.773 & 0.732 & 0.621 & 0.606 & 0.634 & 0.609 & 0.686 & 0.712 & 0.708 \\
\hline
\end{tabular}

$A_{\text {rad }}$ is radiative heat transfer area of the human body. $A_{\text {cod }}$ is conducive heat transfer area of the human body. $f_{r a d}$ is radiative heat transfer area ratio of the human body. Radiative heat transfer area ratio is the ratio of the radiative heat transfer area to the total body surface area. Standing is Standing position. Chair is the chair sitting position. Seiza is seiza sitting position. Cross is cross-legged sitting position. Sideway is sideway sitting position. Knee is both-knees-erect sitting position. Leg-out is leg-out sitting position. Lateral is lateral position. Supine is supine position.

\section{4. 考察}

伝熱面積は被験者の体格や体組成などの影響を受けて変化す る。一方、土川ら (1988)わは人体の全体表面積にて基準化した 人体の有効放射面積を比較㭘討し、基準化したデータには体格・ 体型の影䈏はほとんど認められないことを明らかにしている。 人体の放射伝熱面䆏は、体表面の接触や床面と人体との接触な どが実測結果に支配的影響を及ぼす数值である。そこで、被験 者の体格や体組成などの影鳘を排除し実測結果の比較が可能な ように、全体表面積に対する伝熱面樌の比を伝熱面積比として 表す。

Table 2 に放射伝熱面積比と既存の裸体人体に関する研究と の比較を示す。なお、既存の研究と相互比較が可能なように、 従来の人体と床面との接触面も放射伝熱面積と見做す値も併記 した。

立位の放射伝熱面鉷比は、Bohnenkamp and Pasquary(1931) ${ }^{1)}$ が 0.83、Bandow and Bohnenkamp(1935) ${ }^{2)}$ が 0.83、 Bedford(1935) ${ }^{3)}$ が 0.83、Hardy and DuBois(1938)4) が 0.78、 Guibert and Taylor(1952)5) が 0.77、Fanger et al.(1970)6 0.73、土川ら (1988) $)^{n}$ が 0.80、Horikoshi et al.(1990)9 が 0.80 、 土川ら (1991) $(2000)^{11)}$ が 0.75、宮本ら (2001) ${ }^{12}$ が 0.79 という值を実測によ り得ている。実測方法や姿勢条件の違いが影疃しばらつきがあ るが、0.73 0.83 の範囲の值である。また、いずれの研究とも 伝遵伝熱面樌を放射伝熱面積に含めた処理をしている。本研究 の立位の放射伝熱面積比に伝導伝熱面積を含めた処理をした值 では 0.786 が得られる。

椅座位の放射伝熱面楀比は、Guibert and Taylor(1952) $)^{5)}$ が 0.70、 Fanger et al.(1970) ${ }^{6)}$ が 0.70 、堀越と小林 $(1982)^{13)}$ が 0.75、Kakitsuba et al(1987) ${ }^{14)}$ が 0.70 、土川 $5(1988)^{n}$ が

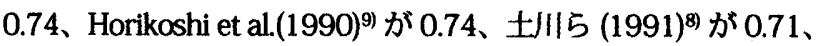
垣鐸と鈴木 $(1997)^{10)}$ が 0.71 、富田ら $(2001)^{15)}$ が 0.73 、宮本ら $(2003)^{16)}$ が 0.76 という值を実測により得ている。実測方法や 姿勢条件の違いが影響しばらつきがあるが、0.70 0.76 の範囲 の值である。また、いずれの研究とも床面との伝導伝熱面積も 放射伝熱面積に含めた処理をしている。本研究の椅座位の放射 伝熱面積に伝導伝熱面積を含めた処理をした值では 0.741 が得 られる。

その他の姿勢についての研究は極めて少ない。正座位の放射 伝熱面積比は、藏澄ら (1998a) $)^{17 か ゙ ~} 0.64$ という值を実測によ
り得ている。本研究の正座位の放射伝熱面積比は 0.621 が得ら れる。胡座位の放射伝熱面積比は、宮本ら (1996) ${ }^{18)}$ が 0.64 と いう値を実測により得ている。本研究の正座位の放射伝熱面積 比は 0.606 が得られる。横座位の放射伝熱面積比は、藏澄ら $\left.(2005)^{19}\right)_{\text {が }} 0.613$ という值を実測により得ている。本研究の横 座位の放射伝熱面積比は 0.634 が得られる。立て滕位の放射伝 熱面積比は、宮本ら (1996) ${ }^{18)}$ が 0.62 という值を実測により得 ている。本研究の立て滕位の放射伝熱面積比は 0.609 が得られ る。

伝導伝熱面積を放射伝熱面積に含めた処理をした值で放射伝 熱面積比を比較すると、Guibert and Taylor(1952)5) の最も放射 伝熱面積比が小さくなるとされているクラウチング姿勢や藏澄 $5\left(1998 \mathrm{a}^{17}, 2005^{19}\right)$ の正座位・横座位、宮本ら $(1996)^{18)}$ の 立て滕位・胡座位、本研究の正座位・胡座位 ・横座位・立て滕 位の放射伝熱面積比は他の姿勢と比較して小さな値となった。 なお、Bedford(1935)3)のクラウチング姿勢での実測最小値は 0.66 が得られている。

これらの姿勢の放射伝熱面積比の值の大小には姿勢の維持状 態が影響していると考えられる。まず、立て滕位は姿勢の維持 状態がクラウチングに近いために放射伝熱面積比が小さくなっ たと考えられる。次に、正座位は椅座位の下腿部を大腿部に密 着させた状態とほほ見做せるために、大腿部の後面と下腿部後 面の体表面が放射伝熱面積に寄与せず、放射伝熱面䅡が小さく なったと考元られる。次に、横座位は正座位の下腿部を前頭方 向に投げ出し、下肢部が躯幹部から突出た姿勢とほほ見做せる ために、横座位の放射伝熱面積比は正座位の值より若干大きく なったと考えられる。また、胡座位の下肢部の片溉部を内旋さ せ下肢部の組み方を変えた状態とほほ見做せるために、両姿勢 の放射伝熱面積比はほぼ同棣な値となったと考えられる。

投げ足位の放射伝熱面積比は、藏澄ら (2005) ${ }^{199}$ が 0.642 と いう値を実測により得ている。本研究の投げ足位の放射伝熱面 積比は 0.686 となり、藏澄ら (2005) ${ }^{199}$ の研究成果よりも大き な値となっている。本研究の放射伝熱面積に伝導伝熱面積を含 めた処理をした值での差は 0.018 となり、大きな差異とはなっ ていない。一方、藏澄ら (2005) ${ }^{19)}$ の投げ足位の伝導伝熱面積 比との差は 0.026 となり、本研究の值が小さな値となっている。 したがって、本研究と藏澄ら (2005) ${ }^{19)}$ の差は伝導伝熱面櫝に よる影響が強いと考えられる。

投げ足位は椅座位の下腿部を伸展させた状態とほぼ見做せる 
Table 2 Comparison of radiative heat transfer area ratio in the previous studies.

\begin{tabular}{|c|c|c|c|c|c|c|c|c|c|c|c|}
\hline Investigator & Standing & Chair & Seiza & Cross & Side & Knee & Leg-out & Lateral & Supine & \multicolumn{2}{|c|}{$\begin{array}{l}\text { Number of subject } \\
\text { Male Female }\end{array}$} \\
\hline Bohnenkamp \& Pasquay(1931) & $(0.83)^{\dagger}$ & - & - & - & - & - & - & - & - & 31 & 30 \\
\hline Bandow \& Bohnenkamp(1935) & $(0.83)^{\dagger}$ & - & - & - & - & - & - & - & - & 42 & 26 \\
\hline Bedford(1935) & $(0.83)^{\dagger}$ & - & - & - & - & - & - & - & - & 2 & - \\
\hline Hardy \& DuBios(1938) & $(0.78)^{\dagger}$ & - & - & - & - & - & - & - & - & 2 & - \\
\hline Winslow et al.(1940) & - & & - & - & - & - & - & - & - & 2 & - \\
\hline Guibert \& Taylor(1952) & $(0.77)^{\dagger}$ & $(0.70)^{\dagger}$ & - & - & - & - & - & - & - & 3 & - \\
\hline Guibert \& Taylor(1952) & - & - & - & - & - & - & - & - & - & 1 & - \\
\hline Fanger et al.(1970) & $(0.73)^{\dagger}$ & $(0.70)^{\dagger}$ & - & - & - & - & - & - & - & 10 & 10 \\
\hline Horikoshi \& Kobayashi(1982) & - & $(0.75)^{\dagger}$ & - & - & - & - & - & - & - & 1 & - \\
\hline Kakitsuba et al.(1987) & - & $(0.70)^{\dagger}$ & - & - & - & - & - & - & - & 5 & - \\
\hline Tsuchikawa et al.(1988) & $(0.80)^{\dagger}$ & $(0.74)^{\dagger}$ & - & - & - & - & - & - & - & 4 & - \\
\hline Horikoshi et al.(1990) & $(0.80)^{\dagger}$ & $(0.74)^{\dagger}$ & - & - & - & - & - & - & - & 4 & - \\
\hline Tsuchikawa et al.(1991) & $(0.77)^{\dagger}$ & $(0.71)^{\dagger}$ & - & - & - & - & - & - & - & - & 1 \\
\hline Miyamoto et al.(1996) & - & - & - & 0.64 & - & - & - & - & - & 3 & - \\
\hline Miyamoto et al.(1996) & - & - & - & - & - & 0.62 & - & - & - & - & 3 \\
\hline Mizutani et al.(1996) & - & - & - & - & - & - & - & $(0.79)^{\dagger}$ & - & 1 & - \\
\hline Kakitsuba \& Suzuki(1997) & $(0.76)^{\dagger}$ & - & - & - & - & - & - & - & - & 2 & - \\
\hline Kakitsuba \& Suzuki(1997) & - & $(0.71)^{\dagger}$ & - & - & - & - & - & - & - & 2 & - \\
\hline Kurazumi et al.(1998b) & - & - & 0.64 & - & - & - & - & - & - & 1 & - \\
\hline Tomita et al.(2000) & $(0.75)^{\dagger}$ & - & - & - & - & - & - & - & - & - & 3 \\
\hline Miyamoto et al.(2001) & $(0.79)^{\dagger}$ & - & - & - & - & - & - & - & - & 3 & - \\
\hline Tomita et al.(2001) & - & $(0.73)^{\dagger}$ & - & - & - & - & - & - & - & - & 3 \\
\hline Miyamoto et al.(2003) & - & $(0.76)^{\dagger}$ & - & - & - & - & - & - & - & 3 & - \\
\hline Kurazumi et al.(2005) & - & - & - & - & 0.613 & - & - & - & - & - & 1 \\
\hline Kurazumi et al.(2005) & - & - & - & - & - & - & 0.642 & - & - & - & 1 \\
\hline Kurazumi et al.(2005) & - & - & - & - & - & - & - & 0.722 & - & 1 & - \\
\hline Kurazumi et al.(2005) & & & & & & & & - & 0.792 & 1 & - \\
\hline Authors & $(0.786)^{\dagger}$ & $(0.741)$ & $(0.633)^{\dagger}$ & $(0.635)^{\dagger}$ & $(0.664)^{\dagger}$ & $(0.632)$ & )$^{\dagger}(0.724)$ & ${ }^{\dagger}(0.752)^{\dagger}$ & ${ }^{\dagger}(0.808)^{\dagger}$ & 1 & - \\
\hline Authors & 0.773 & 0.732 & 0.621 & 0.606 & 0.634 & 0.609 & 0.686 & 0.712 & 0.708 & 1 & - \\
\hline
\end{tabular}

Radiative heat transfer area ratio is the ratio of the radiative heat transfer area to the total body surface area. Standing is standing position. Chair is chair sitting position. Seiza is seiza sitting position. Cross is cross-legged sitting position. Side is sideway sitting position. Knee is both-knees-erect sitting position. Leg-out is leg-out sitting position. Lateral is lateral position. Supine is supine position. ()$^{\dagger}$ value take into account only the area of contact between the body and the floor.

が、両姿勢とも伝導伝熱面積を含めた処理をした値ではほぼ等 しい值となっている。上半身と下半身の相互放射の影響が強く なる投げ足位の放射伝熱面積が若干小さな値となっている。 側臤位の放射伝熱面積比は、水谷ら $(1996)^{20)}$ が 0.79、藏澄 ら (2005) ${ }^{19}$ が 0.722 という数值を実測により得ている。水谷 ら (1996) ${ }^{20)}$ は伝導伝熱面積を放射伝熱面積に含めた処理をし ている。本研究の 0.712 は藏澄ら (2005) ${ }^{19)}$ の実測値とほほ等 しい。

仰臥位姿勢の放射伝熱面積比は、藏澄ら (2005) ${ }^{19)}$ が 0.792 という数值を実測により得ている。本研究の 0.708 は藏澄ら $(2005)^{19)}$ の実測値よりも著しく小さな値となっている。

藏澄ら (2005) $\left.{ }^{19}\right)$ の放射伝熱面積比は藏澄ら (1994) ${ }^{22)}$ の体表 面積算出式による算出值を用いて求めているが、本研究では実 測值を用いて求めている。藏澄ら (2003a) $)^{27}$ は、瘦身型で長身 の日本人の体表面積と藏澄ら (1994)22) の体表面積算出式を用 いた算出值との間には、標準型の日本人と比較して、実測值と の差が大きくなる傾向を指摘している。本研究の被験者は標準
的な体型の被験者であるので、藏澄ら (2005) $\left.{ }^{19}\right)$ と本研究の顕 著な差は基準値となる数值が算定値と実測值の違いの影響であ ると考えられる。また、藏澄ら (2005) ${ }^{19}$ ) の仰臥位の伝導伝熱 面積比との差は 0.033 となり、本研究の值が大きな値となって いることも影稫していると考えられる。

臥位姿勢は、床面との接触部位を除き立位姿勢と比較的似て いる。前述の様に、立位の放射伝熱面積比は 0.73 0.83 の範囲 の值である。側臥位と仰卧位に伝導伝熱面積を含めた処理をし た値は、立位の放射伝熱面積比とほぼ等しい値である。

人体と床面との接触部は、放射ではなく伝導による熱交換に 関与している。上述の結果は、床面との接触面積が大きい床座 位や臥位の姿勢では、人体の放射伝熱面積を求めるには伝導伝 熱面積を考慮することの重要性を示している。また、体表面ど うしが接触したり、体を届曲させる姿勢の放射伝熱面積は、比 較的開放的な姿勢である立位と比較して小さいという姿勢の影 響が顕著に現れることが示されている。 人体の放射伝熱面積は、姿勢のとり方や維持に大きく影響 
を受けて変化する。しかし、宮本ら $(2000)^{30)}$ は姿勢のとり方 や維持に指示を与えた場合と被験者に委ねた場合の実測方法に て、人体と床面との間の接触面積の実测結果と姿勢とを比較検 討し、いずれの姿勢のとり方や維持方法で害測をおこなった場 合でも姿勢の再現性が高いことを明らかにしている。したがっ て、本研究の結果も同様な煩向を示すと考えられるが、さらに データの蓄積を図り検証をしていく必要があると考えられる。

\section{5. おわりに}

人体と周囲環境との間の熱交換量の基準となる人体の伝熱面 積に着目し、熱交換量の算定に必要であるが未整備である熱平 衡式で用いられる人体の放射伝熱面積を被験者を用いた実測に より明らかにした。

姿勢別の放射伝熱面積の具体值を示し、人体の放射伝熱面積 には姿勢の影響が顕著に現れることを明確にした。

本研究の被験者は 1 名ではあるが、新しいデータとして意義 深いものと考えられる。今後は、多くの実測データの蕃積を図

り、平均的な具体值の呈示をしていく必要がある。

\section{部辞}

本研究を行うにあたり、実測・実験にご協力いただいた方々 に心から感謝の意を表します。

\section{引用文朝}

1) Bohnenkamp, H., Pasquay, W. : Untersunungen zu den Grunglagen des Energie- und Stoffwechsels, III Mitteilung, Pflüger's Archiv für die Gesamie Physiologie, 228, pp.79 75, 1931

2) Bandow, F., Bohnenkamp, H. : Üer die Bestimmung der Strahlungsfiăche des Menschen aus seiner elektrischen Kapazităt, Pflüger's Archiv für die Gesamie Physiologie, 236, pp.427 434, 1935

3) Bedford, T. : The effective radiating surface of the human body, Journal of Hygiene, 35, 3, pp.303 306, 1935

4) Hardy, J.D., DuBios, E.F. : Basal metabolism, radiation, convection and vaporization at temperatures of 22 to $35^{\circ} \mathrm{C}$, Journal of Nutrition, 15 , pp.477 497, 1938

5) Guibert, A., Taylor, C.L. : Radiation area of the human body, Journal of Applied Physiology, 5, pp.24 37, 1952

6) Fanger, P.O., Angelius, O., Jensen, P.K. : Radiation data for the human body, ASHRAE Transactions, 76-II, pp.338 373, 1970

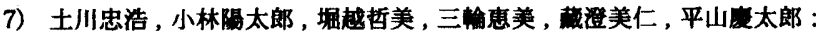
実测による人体の有勃放射面樻および人体と矩形面との間の形怒係数 に関する研究，勇年男子に対する裸体・蓄衣，立位・椅座の場合，日 本建築学会計两系稐文報告集，388,pp.48 59, 1988.6

8）土川忠浩，堀越哲美，近藤恵美，蔵澄美仁，平山度太郎，小林隰太郎 : 実測による人体の有効放射面稓およひ人体と矩形面との間の形热係 数に関する研究，その 2 青年女子に対する実湘および青年男子の部 位に対する実测，日本建築学会計画系論文報告集，428，pp.67 75， 1991.10

9) Horikoshi, T., Tsuchikawa, T., Kobayashi, Y., Miwa, E., Kurazumi, Y., Hirayama, $K$. : The effective radiation area and angle factor between man and a rectangular plane near him, ASHRAE Transactions, 96-I, pp.60 66, 1990

10）垣鏗直，鉿木健次 : 着衣のゆるみ度が有効放射面積率に及ぼす影慗に 関する研究，日本建筑学会計画系諭文集, 500,pp.37 41, 1997.10

11）富田明美，宮本征一，堀越美美，垣鎋值 : 着衣のゆとりが人体の有効 放射面栍と形势係数に及ぼす影䈏に関する研究 1 青年女子被験者を
用いた立位姿勢の場合，日本建築学会計画系誝文集， $528 ， \mathrm{pp} .37 \sim 42$, 2000.2


放射面積と形琶係数に及ぼす影鳌に関する研究 2. 青年男子被験者を 用いた立位姿勢の場合，日本建築学会計画系論文集，539，pp.23 28， 2001.1

13）堀越哲美，小林陧太郎 : 人体と矩形面との間の形態係数および人体の 有効ふく射面稘に関する研究 第 2 報 椅座裸体の埸合の実眼と考察， 日本建筑学会論文報告集 , 322,pp.92 100, 1982.12

14) Kakitsuba, N., Michna, H., Mekjavic, I.B. : Clothing surface area as related to body volume and clothing microenvironment volume, Aviation, Space, and Environmental Medicine, 58, 5, pp.411 416, 1987

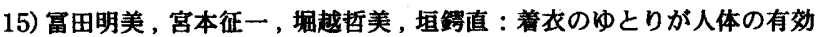

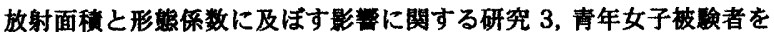
用いた椅座姿勢の場合, 日本建策学会計画系論文集, 547, pp.27 32, 2001.9

16）宮本征一，冨田明美，堀越拍美 : 着衣のゆとりが人体の有剂放射面稓

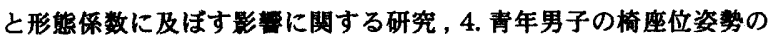
実浿および性別・姿势問の检㣙，日本建築学会計画系論文集，569， pp.15 20, 2003.7

17) 藏澄美仁，松原紊樹，鸣海大典，長野和雄，土川忠浩，场越哲美 : 姿勢

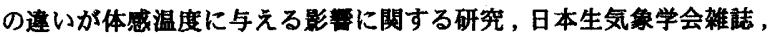
$35,1, \mathrm{pp} .35 \sim 44,1998 \mathrm{a} .4$

18）宮本征一，谷口芳榯，崔英植，土川忠浩，堸越哲美：床座時の人体有 効放射面積と形憗係数に閣する研究，日本建築学会計画系諭文集， 497, pp.27 33, 1996.7

19）藏登美仁，土川忠浩，大和義昭，中谷岳史，松原斎㴻，堀越哲美 : 放射 冷暖房空間における人体の放射熱収支に関する研究，横座位・投げ足 位 - 側卧位 - 仰臤位の人体の有効放射面積と人体の矩形面との䦓の形 俰数，空気碉和・衙生工学会論文集，97, pp.1 14, 2005.4

20) 水谷朋子，䤃澄美仁，松原商檄，鳴海大典，長野和雄，土川忠浩，堀 越哲美 : 横卧位人体の有効放射面稓之室内椣成面との間の形怒倸数の 実測，日本建築学会大会学術祥演梗概集 D 環境工学, pp.349 350, 1996

21）藏澄美仁，土川忠浩，大和義昭，角谷孝一郎，松原少槽，䏱越哲美 : 姿

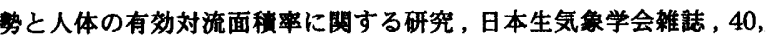
1, pp.3 13, 2003b.5


る研究, 日本生気象学会雑誌, 31, 1, pp.5 29, 1994.4

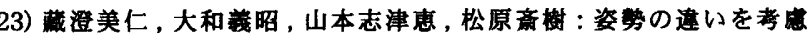
した平均皮店温算出法に関する研究，日本生気曼学会蓶誌，34, 4, pp.101 112, 1997.12

24）堀越折美，宮原英男，小林阳太郎 : 人体と矩形面との間の形管保数お よび人体の有奻ふく射面樻に関する研究，1. 算出理酮と椅座萑衣の場 合の実测，日本建築学会詥文報告集，268,pp.109 119, 1978.6


盖情報研究会，国民栄蓝の現状，pp.101 103, 第一出版，東京，2004

26）藏澄美仁，松原产檄，長井秀檄，古川倫子，藤原三和子，上麻美，植木 弥生, 山本志津恵 : 温熱環境評価と热伝導に関する研究, 空気拥和・ 峝生工学会詥文集, 72, pp.23 34, 1999.1

27）藏澄美仁，土川忠浩，角谷孝一郎，鳥居孝行，松原高榯，堀越哲美 :

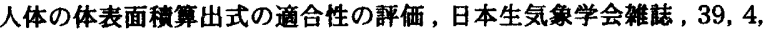
pp.101 106, 2003a.2

28）藏澄美仁, 松原赢樹, 古川偷子, 藤原三和子, 上麻美, 植木弥生, 長井 秀樹，山本志津恵: 姿勢の違いと日本人の平均皮虔温算出法, 日本生 気象学会雑誌 , 35, 4, pp.121 132, 1998b.12

29) Kurazumi, Y., Tsuchikawa, T., Matsubara, N., Horikoshi, T. : Convection heat transfer area of the human body, European Journal of Applied Physiology, 93, 3, pp.273 285, 2004.11

30）宮本征一，冨田明美，堀越哲美 : 床座位を中心とした各姿勢における 接触面積比の再現性に関する研究，日本建築学会計画系詥文集，532， pp.23 27, 2000.6 